\title{
Networking and the Role of the Academic Systems Librarian: An Evolutionary Perspective
}

\section{Merri Beth Lavagnino}

This paper explores the role of the academic systems librarian from an evolutionary perspective, with a primary focus on the effect that networking technologies have had on this role. Stages of evolution of this role are described, using examples from the literature and from surveys taken over the past few years. The author discusses new tasks the systems librarian has added as a result of this fundamental technological change, outlines trends in the field that are occurring in reaction to this change, and proposes some thoughts for the next stage of development of the systems librarian role.

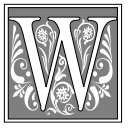

ith the growth of local, national, and international networking initiatives, the role of the academic systems librarian has undergone a fundamental change. This has occurred with little mention in the literature and little formal acknowledgment in the profession; in fact, the role of the systems librarian in general has been a little-researched topic. In 1988, Susan K. Martin acknowledged and addressed this void in her article, "The Role of the Systems Librarian," in which she stated, "Systems librarians ... have been almost entirely ignored, together with attendant issues such as their role, qualifications, and future." ${ }^{1}$ In the years since her article was published, a few surveys have told us more about the systems librarian's role, most recently, the ALA Library Administration and Management Division's Systems and Services Section (SASS) study, ${ }^{2}$ the 1995 revision of the Association of Research Libraries (ARL) SPEC Kit on Systems Office Organization, ${ }^{3}$ and Graeme A. Muirhead's study in the United Kingdom. ${ }^{4}$ None of these surveys has focused on the history or evolution of the systems librarian's role, however, or on the specific changes to it occasioned by networking technologies, although each of them presents information that makes it clear that such changes are occurring. This paper discusses new tasks the systems librarian has added as a result of this fundamental technological change, outlines trends in the field that are occurring in reaction to this change, and proposes some thoughts for the next stage of development of the role of the systems librarian.

To understand the effect of networking on the systems librarian's role, it is helpful to look at the position's overall evolution. Much analysis of this evolution must be based on personal experi-

Merri Beth Lavagnino is the Library Systems Director at the University of Illinois at Urbana-Champaign; e-mail:mbl@uiuc.edu. 
ences of systems librarians because there is a lack of documentation of the actual role and the pressures that were changing it. It also is important to note that there are many individual variations on the evolution of systems librarians, as academic libraries differ widely in size and organization and in their current level of automation. Many smaller academic libraries do not yet have, or have just recently acquired, a systems librarian. Others (generally the larger libraries) were part of early automation efforts and now have systems librarians and departments at the higher stages of evolution.

The term systems librarian is used throughout this paper for the sake of consistency. This discussion is intended to be about the person who is in charge of managing automation in the library. It should be noted that there are many variations in the job titles of these people,

\section{Many smaller academic libraries do not yet have, or have just recently acquired, a systems librarian.}

including head of library systems, automated systems coordinator, library systems manager, and director of systems. ${ }^{5}$ In addition, it is true that not all of these individuals are librarians, although surveys taken in the past few years indicate that the majority are trained as librarians. ${ }^{6}$

\section{A Model and a Beginning}

A simple stage model is used here only to help organize and conceptualize the evolution of the systems librarian role. Although stage theorists work to perfect a model to describe various social or technological phenomena, the stage model used here is illustrative of only very basic categorizations of systems librarian duties. Libraries may go through all these stages or may skip or reorganize them, but starting with a basic model allows us to begin thinking about the changes that have occurred, what may be causing them, and how systems librarians and their organizations are responding to them. A chart listing these stages and summarizing the systems librarian's evolution is shown in figure 1.

The first identifiable stage probably was when libraries moved away from handwritten catalog cards to typewritten cards, and the administrative and acquisitions departments moved from hand calculations to adding machines. This was the first step toward the automation of libraries. ${ }^{7}$ In fact, this stage marked the introduction of the keyboard and the number pad to the library staff. Although a systems librarian position was not designated at the time, certainly people in the organization were analyzing work flow and the effect the new machines would have on it, determining whether they would be a cost-effective alternative to manual work, selecting and ordering them, installing them and arranging for maintenance, and training staff in how to use them.

\section{The Systems Librarian Role Is Born}

A second stage encompassed the period of development of mainframe and minicomputer technologies and thus the development of function-specific automated library systems. At first, these systems were offline, batch-processing systems, typically using punch cards for data entry. Many early circulation systems, for example, automated the circulation of items though the use of punch cards created and placed in the pockets of the items. Later in this stage, online time-sharing systems were developed and this technology was used by many early library automation projects. ${ }^{8}$

The systems librarian first appeared during this stage. He or she was concerned with mainframe and minicomputer systems development and implementation, and usually was found working for bibliographic utilities, vendors, or large university libraries developing 


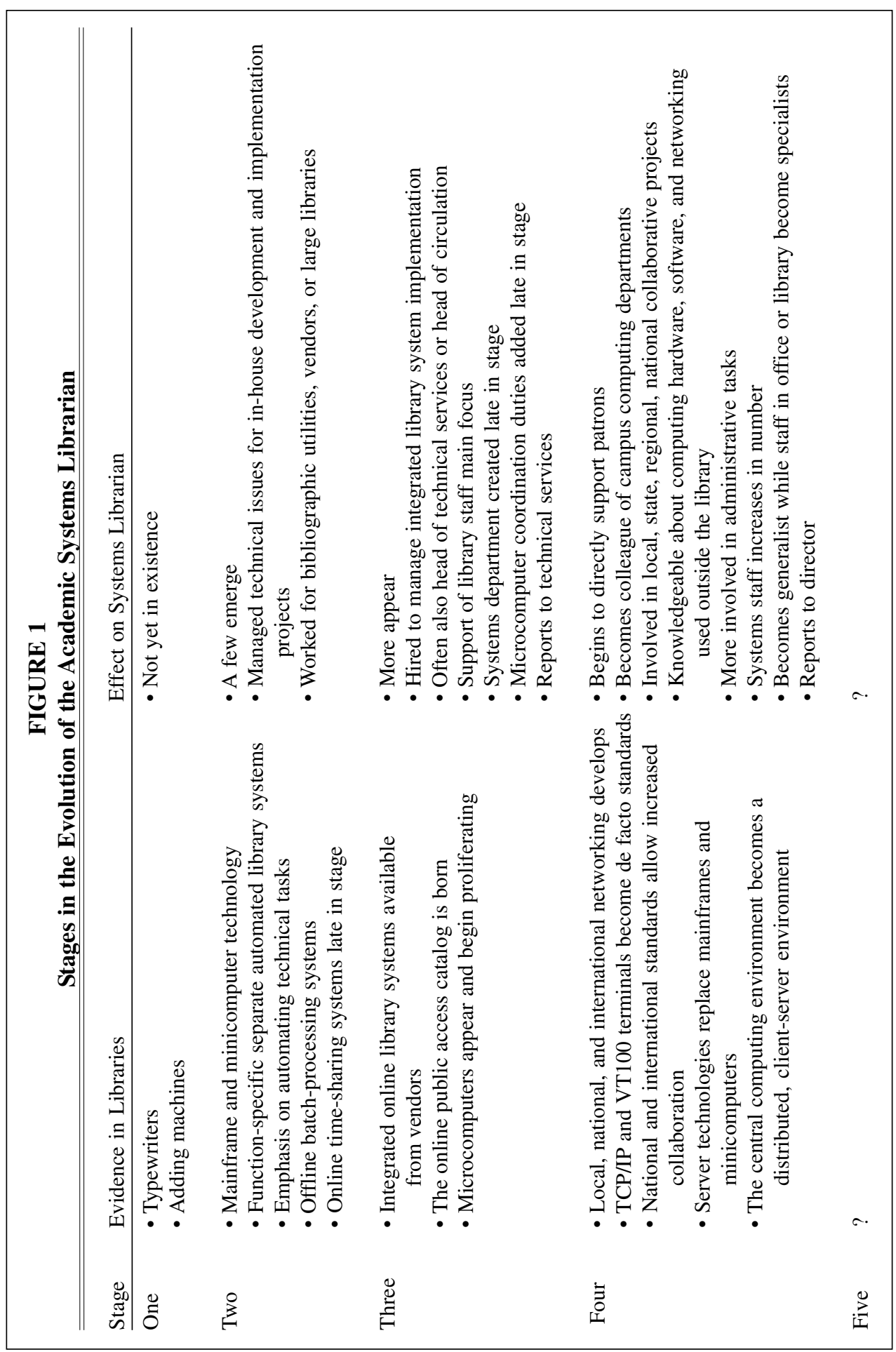


in-house systems. The systems generally were developed to handle functions used by staff, such as circulation or acquisitions; few public services functions were automated. ${ }^{9}$ These systems librarians dealt mostly with technical issues such as setting terminal characteristics, managing appropriate inputs and outputs to

\section{Systems librarians were a rarity, though, and many libraries brought computing staff with no library training into systems projects.}

and from the system, running indexing jobs, and backing up the system. This involved interacting with programmers in developing the system and with technicians in keeping it running, and sometimes in operating the system and training library staff. These early systems librarians did not interact with the public - the college or university students, staff, and faculty - but, instead, were limited to working with library and computer center staff and faculty.

Systems librarians were a rarity, though, and many libraries brought computing staff with no library training into systems projects. "Individuals possessing both knowledge of library operations and computer expertise as applied to library functions constituted a small, informal elite in the library profession," remarks Charles R. Hildreth about the period before the 1980s. ${ }^{10}$ In a 1978 article titled "Automation and the Library Administrator," Eleanor Montague states that these new systems offices were "populated by systems analysts and programmers" and that "the majority of the time, library management did not possess the expertise to properly direct or evaluate the system development effort."11 However, at least two articles published in the early 1980s on selecting automation project managers recommend someone outside the systems office as the best choice for the job. ${ }^{12}$ Oddly, one of these articles tells us that "in general, a line officer with proven managerial ability, a global view of the library, a sufficiency of systems expertise, and a strong sensitivity to system users' needs is the best choice for the library's project manager."13 To modern systems librarians, this may sound like a current listing of required skills for their position! It is clear that although the concept of the systems librarian was born in stage two, the merger of the "librarian" and "systems" roles would not begin to occur until at least stage three.

\section{The Role Expands: The Systems Department Emerges}

In the third stage, the systems librarian's role expanded beyond the technical tasks handled in the previous stage. Technological advances enabled separate, function-specific automated library systems to evolve into integrated online library systems, adding the first public function in the form of online public access catalogs. In 1987, Hildreth stated that "most formal plans for acquiring a local automated library system now specify a multi-function, integrated library system that can be operated entirely at the local site." ${ }^{14}$ Perhaps as a result of this, many libraries hired a systems librarian or reallocated an existing librarian to coordinate the selection and implementation of a commercial integrated system. He or she often had a technical services or circulation background, and many librarians who performed these tasks did them not as an official systems librarian but as part of some other position, such as head of technical services or head of circulation. During this stage, those desirable project management skills were merged with the technical systems skills, and the systems librarian role began evolving into the more modern conception, truly merging "systems" and "librarian" skills into one position.

During this same time period, microcomputers began to proliferate in librar- 
ies. Interestingly, the mainframe/minicomputer systems and the microcomputer systems did not appear to receive the same level of attention at the beginning of this stage. In most cases, the systems librarian's role (and attention) was focused only on mainframe/minicomputer systems and the dedicated terminals that accessed them. One respondent of the SASS survey stated: "microcomputers, CD-ROMs, Internet, e-mail were not in my area of concern. My only concern was the mainframe library system design and implementation."15

This focus may have occurred because in most libraries microcomputers surfaced without real planning. While the systems librarian was busy managing implementation of the new integrated system, staff members who liked to experiment with new things, enjoyed reading manuals, and were not afraid of computers became the unofficial microcomputer systems support persons. This caused tension when these persons began to spend too much time helping other departments with their microcomputers and not enough time doing the job they were hired to do in their own department.

In addition, as the applications available on microcomputers became more and more useful for library tasks that were not handled by the integrated system (including word processing, spreadsheets, and dial-up access to reference databases), the stress on administrators trying to manage these machines and their applications became unbearable, especially in larger libraries. Individual library departments were not coordinating their microcomputer purchases and activities with other library departments, and widely varying (and often incompatible) hardware and software were being purchased from multiple vendors with inconsistent pricing and maintenance service. Departments with the unofficial microcomputer systems support persons were advancing technologically and those without these necessary staff were being left behind.

These combined stresses led to expansion of the systems librarian role and to development of the systems department. Mainframe/minicomputer and microcomputer duties were merged under the auspices of the systems librarian, and the microcomputer activities in all the library departments began to be coordinated centrally. The integrated systems librarian was assigned a staff member or two, if possible, and a systems department was born that could support not only the mainframe/minicomputer integrated system but also other specialized tasks that could be accomplished with microcomputer applications. These tasks included typing in and saving written documents that needed to be revised often, creating specialized databases to manage information that was neither appropriate for nor possible to include in the bibliographic catalog, and managing financial figures with spreadsheets. In those cases where no staff members were hired or reassigned to the fledgling department, the staff who had unofficially supported microcomputing sometimes continued to do so for their own department, now in cooperation with the systems librarian, who would support those departments where no unofficial expert had emerged. Perhaps this broadening of duties was made possible by the move to vendor-developed systems and by completion of the implementation phase, which left more time for these new activities.

These changes meant that the systems librarian began to supervise staff, to work closely with all departments of the library and all levels of staff, and to perform some administrative functions in terms of librarywide automation planning, budgeting, decision-making, and purchasing. However, he or she was often still organizationally located under the assistant director or head of technical services or circulation because much of 
the automation was still centered on cataloging, serials, acquisitions, and circulation. In an early SPEC Kit on systems office organization in 1986, it was noted that although some systems librarians reported to the library director:

In other situations, the systems office forms a department that is part of one of the major operational areas of the library, such as technical services or circulation. [This choice of reporting line] can be a function of the subsystem that was implemented first, the location of interested staff members, or even the physical location of major computing equipment. In the study of organization charts, fourteen systems offices were a part of technical services, six reported to an associate director for administrative services, and three to access services. ${ }^{16}$

The systems librarian may have had some minimal contact with the public at this stage, with the introduction of the online public access catalog and of stand-alone CD-ROM technologies, but it was not substantial. Support of library staff continued to be the focus.

\section{Networking Alters the Role}

In the fourth stage, local, national, and international internetworking developed and the duties of the systems librarian expanded even more as a result. Although there were networks in place in previous stages (for example, those that allowed libraries to access the bibliographic utilities and those that allowed terminals throughout the library to access their integrated system), these were limited applications because of the dedicated nature and specialized protocols of the networks. With the introduction and popularity of de facto standard protocols for communication such as TCP/IP and the VT100 terminal, internetworking of networks in order to communicate be- tween systems from different vendors using differing communications protocols became possible, and newer technologies developed as a result of this networking. ${ }^{17}$

Library literature and conference programs indicate that many of the mediumsized to large academic libraries are currently in this stage of evolution of the systems librarian role. Smaller academic libraries that may still be in one of the earlier stages may have to skip stages when they find themselves inundated by networking and its effect on information delivery to both the public and the library faculty and staff. At the Computers in Libraries Conference in 1991, Clifford A. Lynch was already outlining the technical and management issues of this stage in his presentation titled "Evolution in Action: The Demise of the Integrated Library System and the Rise of Networked Information Resources." 18 Some of the major changes to the role of systems librarian as a result of internetworking include: expansion of the clientele the systems librarian serves; an increase in the number and type of interactions with on-campus computer support departments as well as off-campus local, regional, and national systems librarians; a demand for more technical skills relating to the complexities of networking; and an escalation of administrative and professional commitments.

\section{Serving More Than Just the Library}

As networking became more pervasive, the academic systems librarian's role expanded to include serving college or university faculty, staff, and students. The work done by the systems librarian in the previous stages typically served patrons only indirectly by providing the public catalog, perhaps installing some standalone CD-ROMs in the library, and by supporting the systems needs of librarians and staff (for example, reference librarians and bibliographers) who, in turn, supported patrons directly. The sys- 
tems librarian rarely supported or interacted directly with library patrons. With the advent of campus networks, the systems librarian began to support patrons directly by creating and maintaining networked electronic information systems and then by providing access to those electronic services from patrons' offices and homes. Although the reference librarians answer questions about how to use a resource once connected to it, they refer patrons to the systems librarian for help if the patron has technical difficulties connecting to the service. In addition to responding individually to patron problems with accessing the library's electronic resources, the systems librarian often began producing documentation for patrons, such as a sheet describing how to dial in to the online catalog, a task not generally performed in previous stages of evolution.

Scott P. Muir, in summarizing the results of the 1995 SPEC Kit survey on library systems office organization, reinforces this shift toward supporting not just library faculty and staff, but also library patrons:

Three activities, all reflecting the trend toward increased patroncentered activities, showed tremendous increases. The largest percentage increase was systems offices working on Gopher, Mosaic, etc. Fifty-seven libraries reported involvement in this area, compared with only five libraries in 1990, an increase of more than $1000 \%$. In a related activity, twenty-five libraries were working with CWIS in 1994 while only three were doing so in 1990, a $733 \%$ increase. Patron access to remote databases (e.g., CARL UnCover, OCLC FirstSearch) showed a $475 \%$ increase with forty-six systems offices working in this area, up from eight in 1990. Locally mounted databases (up $218 \%$ ) and networked CD-ROMs (up 118\%) showed substantial increases as well. ${ }^{19}$

Support of faculty, staff, and students in accessing the library's electronic resources often leads to consulting with this clientele on other networking and electronic information needs. The systems librarian is often called upon to explain the value of the campus network to academic departments considering installing network connections because the library often provides the major information resources available on it. When departments create informational data-

\section{The systems librarian rarely supported or interacted directly with library patrons.}

bases, such as specialized citation indexes, preprint databases, geographical information systems, grant information databases, and other databases of local interest, they often approach the systems librarian to ask how to provide access to their information for library patrons. Requests to make computer-based textbook materials, tutorials, and programs available on reserve and usable within the library are growing, requiring assistance from the systems librarian to support the necessary equipment for patrons to use such materials. Systems librarians also are asked for advice when special, often nonlibrary units would like materials such as museum collections, photography collections, career development collections, and computer-aided instruction videos added to the online catalog. The systems librarian is asked how to configure the integrated library system to accept and index these materials, often requiring him or her to meet with the unit that owns the collection. When college and university faculty and staff are writing grants involving electronic information access and networking, the systems librarian is asked for advice and 
ideas as well as for a commitment to become involved if the grant is received.

Muirhead notes that "a point which emerged from a considerable number of replies was that as technologies merge, making the distinction between the library system and the range of other internal and external [information technology] systems less distinct, and as open systems make physical access to the library collection less important, so the role of the systems librarian is not only widening but also evolving from an essentially supporting role into a more high profile post, providing a direct service to a range of customers." ${ }^{20}$ This range of customers includes not only library patrons, but also other campus computing staff and other local, regional, and national library and campus computing staff.

\section{Campus Computing Staff As Colleagues}

Networking initiatives have changed the type and number of interactions with campus computing and telecommunications departments. In the previous stages, the library generally had dedicated terminals connected to a mainframe/minicomputer either in the library or at the computer center, and dealt with a small number of central computer center staff for assistance with this system. Typically, the computer center served as a resource for the systems librarian; rarely was this role reversed.

In this stage, however, the number of interactions has expanded and the role is sometimes inverted. This happened as libraries branched out into networkbased automation projects outside the realm of the integrated library system, or when they moved away from mainframe/minicomputer technologies to newer server technologies that may be fully supported within the library. The systems librarian begins interacting with staff in all divisions of computing, not just the division that supported the main- frame or minicomputer in previous stages. He or she establishes and cultivates relationships with both academic and administrative systems groups, microcomputer services, networking services, extension services, continuing education, and specialists in areas such as graphics, imaging, and instructional technology. Campuswide technology issues such as the security of passwords and data passing through the network are discussed together, including policy issues such as whether to collaborate to make it possible for each patron to have a single user name and password for all electronic services available on campus. The systems librarian and the computer center staff find themselves attending the same conferences sponsored by organizations such as EDUCOM, CAUSE, and $\mathrm{CNI}$, and, in fact, the costs for the institution to join these organizations are often shared by these units. The systems librarian becomes a colleague of the computer center staff, rather than a customer.

As this collegiality grows, the computer center begins to call on the systems librarian as a resource person, reversing the typical role. Users calling the computer center to ask about campus access to Medline, Current Contents, LEXIS/ NEXIS, Dow Jones News/Retrieval service, or other commercial databases often get referred back to the systems librarian by his or her computing center colleagues, who expect the systems librarian to be able to resolve technical problems or to direct the user to the correct public services unit for assistance. Computer center administrators looking to reduce reliance on expensive mainframes/minicomputers are asking systems librarians to find alternate platforms on which to run integrated library systems (for example, moving to less costly UNIX servers), as well as alternative ways to accomplish tasks through the network rather than through dedicated lines and hardware, and alternative ways to deliver print-based and reel-to-reel 
tape-based inputs and outputs to and from the library system using the network. "Yes, responsibilities have expanded beyond implementation and support for local systems to include strategic planning for networking and telecommunications issues library wide, integration of external electronic resources with traditional library resources, [and] liaison with [the] campus computing center for both library and academic computing issues," writes a respondent to the SASS survey. ${ }^{21}$

The systems librarian also begins to cultivate relationships with computing departments beyond the central computer center. Often there are computing departments within colleges and schools, and the systems librarian is one of the few individuals on campus who will deal with all such units. Typical projects involve providing access to information created and maintained by the college or school; providing access to subjectspecific information through specialized interfaces; pooling resources to provide access to subject-specific resources; planning projects such as access to Internet resources from dorm rooms, extension campuses, and continuing education sites; and so on. The systems librarian begins to be invited to take part in college, school, and campuswide committees and groups addressing such subjects as reviews of currently available technology, strategic planning, and campuswide standardization of technology. This trend is noted in Tim Lynch's article, "The Many Roles of an Information Technology Section," in which he describes one role of a Cornell University systems office: "We work with related campus academic units to integrate the library's capability to manage electronic resources into the strategic plans for curriculum, research, and extension." As an example, he describes his own participation on an advisory committee on electronic information technology in the university's College of Agricultural and Life Science. ${ }^{22}$
Libraries that participated in the 1995 SPEC Kit survey also indicate that they are in this fourth stage and experiencing this change in relationship: "Accountability may become increasingly blurred if the library assumes responsibility for Internet/Web training or operates in a distributed computing environment. The client-server environment will require that the systems office staff and individuals in other departments become skilled at diagnosing problems and find ready solutions. Service lines may also become clouded when academic departments acquire services such as document delivery or electronic bibliographic databases." 23

The existence of networking standards and infrastructure in this stage makes it possible for local, regional, national, and even international collaboration to increase. These initiatives are a result of the desire to pool resources to provide more information to all of the affected institutions, as well as to the general public. Systems librarians find themselves collaborating with other libraries to set up reciprocal Z39.50 access to each other's catalogs; to facilitate online interlibrary loan and document delivery services between libraries; to provide access to locally produced data through these networks; to share in licensing costs for electronic resources; and to share in the loading of those licensed data at one of the participant's sites and accessing it from the others. In all of these and other network-based collaborations, the systems librarian increases interaction with library and computing colleagues outside their own campus, and with other types of institutions such as state libraries, public libraries, school libraries, and library consortiums.

\section{Increase in Technical Knowledge}

In the previous stage, the library focused on a limited number of hardware and software platforms. The systems librarian must now add telecommunications 
standards, protocols, terminology, wiring, and more to his or her knowledge. He or she also must be knowledgeable about not only the hardware, software, and networking technologies chosen for use in the library, but also those used campuswide in order to provide networked services that are accessible from the commonly used technologies on campus. In those libraries actively working to cooperate with other local, regional, and national libraries, the systems librarian needs to be conversant with the relevant national and international standards, know about the technologies used

\section{Those who have been systems librarians for years were trained using those centralized mainframe/ minicomputer environments with their dumb terminal or telnet access methods.}

by these other libraries, and be flexible enough to make the necessary changes to the local environment in order to take part in standards-based networking activities. In the report on the SASS survey, Barbara G. Leonard found that "There is a much higher level of knowledge required than one might expect for telecommunications and LANs. This is especially striking, since on most campuses, telecommunications is not part of the library." 24

The increase in technical knowledge required to perform well as a systems librarian in the networked age is truly an increase, not merely a retooling. Those who have been systems librarians for years were trained using those centralized mainframe/minicomputer environments with their dumb terminal or telnet access methods; and in stage four they must begin working with significantly different technologies and their new culture without losing their knowledge of the older technologies, which do not magically disappear overnight. These new, networked, distributed technologies (for example, client-server computing environments, UNIX workstations acting as powerful servers, World Wide Web servers, newer programming technologies such as object-oriented design, and newer database technologies such as relational database design and SQL) must be learned on the job, while still running the old system. Newer systems librarians may come to the job with more experience with current technologies but no knowledge of the older technologies, which they must learn about in order to begin working within these larger spheres of collaborators who will have a mix of old and new technologies that must interoperate.

The complexities of this new, networked environment are an additional burden. Because it is made up of many different pieces linked together, no single vendor can resolve all the internetworking problems. This heterogeneous environment causes headaches for even the most skilled and knowledgeable systems librarian, who must determine how to make the pieces interoperate and also must be able to figure out exactly what piece is not working when some part of the system fails. In previous stages, all parts of the system were typically within the control of the systems librarian, or at least the campus computing and telecommunications staff, but in this new networked stage, many parts of the internetworked system are beyond their control. They must work with other constituencies, both on campus and off, to identify and resolve interoperability problems.

\section{Escalation of Administrative and Professional Tasks}

In this stage, the systems librarian is more involved in the strategic planning activities of the library, in order to advise on and implement the appropriate technical infrastructure for the services desired. He or she becomes more involved in the librarywide budget, perhaps as a result 
of spending a significant portion of it on creating and maintaining the various networked systems. Also, he or she becomes more concerned about building maintenance and security, shipping and receiving, and administrative office functions. This is a result of becoming involved in the building wiring component of networking; becoming concerned about the effect of power outages and other emergencies on automated and networked systems; having to distribute large pieces of equipment and the attendant furniture to library units; needing to order hardware and software quickly to resolve problems; and working to prevent the theft of automation equipment.

Planning and budgeting projects go beyond the local library in this networked stage, and the systems librarian consults with other specialist technical persons on campus and within their group of off-campus collaborators to plan and write proposals and grants for projects aimed at increasing information access beyond the library and the campus. In these times of financial constraints in educational institutions, such proposals often come to fruition by joining together funds from several departments or institutions in order to produce a service for the whole campus, state, or region. The systems librarian now spends much time attending professional conferences and meetings, in correspondence, and on conference calls in order to plan, implement, monitor, and lead such projects.

It is interesting to note that in the SASS survey, the top skills required by a systems librarian are, in this order: problem solving, planning, oral communications, interpersonal, written communications, organizational, negotiating, and supervisory. ${ }^{25}$ It is interesting to compare this to stage two when the systems librarian was typically a "computing" person and considered unfit to be the project manager for automation projects.

\section{What Gives?}

If systems librarians in this networked stage are adding all these activities to their list of duties, what have they stopped doing?

In many cases, particularly in smaller libraries, they have not stopped doing anything; they are just doing more. Muirhead found that 62.8 percent of his respondents regularly worked beyond their contracted hours, and an additional 32.3 percent said they did so occasionally. ${ }^{26}$ But there are some activities common in previous stages that are difficult to continue doing well because of the addition of seemingly higher-priority networking activities, including:

- microcomputer hardware installation, troubleshooting, and repair;

- microcomputer software installation and troubleshooting;

- integrated library system software maintenance such as resolving nonurgent bugs;

- routine analysis of work flow and identification of tasks that could be made more efficient through hardware or software modifications;

- staff training.

As seen in the next section, these activities continue to get done, but apparently not by the systems librarian. Although most academic libraries are currently entering into and struggling with this networked stage, there are some emerging trends that may help solve the problem of supporting traditional activities in addition to the new networking activities.

\section{Evolution during This Networking Stage}

The systems department appears to be expanding during this stage to meet the growing computing needs of the library. In a study of employment advertisements in American Libraries for academic librarian positions, the number of position announcements for systems positions steadily increased from one in 1974, to 
thirteen in 1979, to twenty-three in 1984, to thirty in 1989 , to forty-three in $1994 .{ }^{27}$ The 1995 SPEC Kit survey found a 37 percent increase in systems office employees overall since 1990, including a 205 percent increase in the number of network specialists, a 55 percent increase in student assistants, a 33 percent increase in computer specialists, and a 30 percent increase in librarians. ${ }^{28}$ But besides sim-

The other systems department
librarians and staff are becoming
specialists in particular areas,
knowing all the in-depth technical
details about their particular areas
and a few details about other areas.

ply multiplying, the persons within the systems office have changed roles. Typical systems departments in mediumsized to large academic libraries in the previous stage consisted of a systems librarian as head of the department and perhaps one or more staff members handling technical and programming duties. In reality, though, all the members of the department, including the systems librarian, handled most duties interchangeably, and in smaller institutions the systems librarian did not have any other staff. It was not uncommon in the previous stage to see the systems librarian unjamming a printer or installing a microcomputer, for example.

We are beginning to see, especially in medium-sized to large libraries, the addition of professional librarians to the department as well as additional staff. The head of the department is becoming a technical generalist, knowledgeable about the big picture and competent in management and planning skills, knowing high-level technical details about everything. The other systems department librarians and staff are becoming specialists in particular areas, knowing all the in-depth technical details about their particular areas and a few details about other areas. This is especially apparent from the huge growth of network specialist positions mentioned above, and in the United Kingdom survey in which Muirhead states: "For example, one solution to the problem of increasing workloads was to allocate more staff to the systems unit. This was frequently qualified by a desire for staff with appropriate skills, and in a few cases it was seen as a way of allowing the systems librarian to concentrate on a narrower range of activities, or to develop a more strategic role." ${ }^{29}$ In 1990, Felix T. Chu concluded that the systems librarian, besides being a librarian with experience in library automation, "must also be a software engineer, a hardware specialist, a systems programmer, a telecommunications expert, and an electrical engineer." ${ }^{30}$ As we found when the systems librarian position was first born, only a very small elite can claim to meet these specifications. Specialization is evolving out of necessity as technology becomes more complex and as it becomes increasingly important for the systems librarian to take part in planning and management activities.

In fact, librarians in other departments may become these specialists, because of either a lack of funds to create new positions or a strategic choice to locate such tasks at the department level. In this way, the traditional tasks that are becoming increasingly difficult to continue supporting will receive attention. In some cases, this trend is already emerging - examples of common, newly described positions are the library training coordinator position (for staff training in technologies in addition to bibliographic instruction) and the reference librarian (or high-level assistant director position in some of the larger libraries) assigned the duty of coordinating electronic information services. In addition, many libraries are experimenting with distributing routine hardware and software installation, maintenance, and repair to departmental systems liaisons and with providing 
centralized training and ongoing support for these liaisons. This can be a particularly effective strategy in libraries where there is still only one systems librarian, as Muirhead notes: "For example, the diffusion of basic systems knowledge to a core of interested staff is one way of promoting a greater understanding of the systems role, easing the systems workload, and ensuring greater operational efficiency by reducing dependence on one individual." ${ }^{31}$

The systems librarian is moving up in the administrative structure of the library, now reporting directly to the director of the library or becoming an assistant director for systems. As early as 1990, in a Dynix survey of systems administrators, two-thirds of the 148 survey respondents reported directly to their library or consortium director. ${ }^{32}$ The 1995 SPEC Kit survey also confirms a move in this direction since $1990,{ }^{33}$ and in the United Kingdom, 66.1 percent of systems librarians report directly to directors or their deputies. $^{34}$ This more closely fits the role of the systems librarian in meeting the needs of all departments of the library, not just the technical services area.

As a result, the systems librarian also has become very involved in the overall administration of the library, which enables him or her to either delegate parts of these duties to others outside the systems unit or create administrative support structures that assist in efficient systems support activities. Having more control over the administration of these processes helps the systems librarian accomplish more with less time and fewer staff. However, Muirhead aptly points out that "the systems librarian's authority seems to be particularly ambiguous. It does not rest on the existing framework of the organization, but cuts across it in a matrix structure, with staff from many departments reporting to the systems librarian in matters of system operation and/or performance." ${ }^{35}$ Perhaps this is one reason why the role of the systems librarian has been so complex and difficult to describe.

\section{What Next?}

The fundamental changes that have taken place in the role of the systems librarian in the fourth, networked stage include: a new clientele in the form of the library patrons; an increase in interactions with computer and networking support departments locally and systems librarians in collaborating institutions; an increase in technical knowledge needed to plan and manage network-based projects; and more administrative and professional commitments such as proposal and grant writing, librarywide planning and budgeting, and attendance at meetings and conferences. But what will cause the next stage of evolution of the systems librarian role to occur, and how will it affect the systems librarian?

Although recent trends are already signaling further changes to the role of the systems librarian, it is hard to imagine what trends might cause a fundamental change of the magnitude that occurred when networking entered our world. We can look to the trends emerging in higher education that will affect organizational and technological strategies, such as those listed in a recent CAUSE publication: (1) traditional funding sources are flat or decreasing; (2) public expectations and state mandates are calling for more reporting requirements and accountability; (3) consumer expectations demand more sophisticated services requiring greater access to data; (4) evolving organization structures will significantly change traditional hierarchies; and (5) sophisticated knowledge workers require expanded technical and consulting support. ${ }^{36}$ Will one or more of these alter the role significantly? We can look to the traditional systems librarian skills that are now being transferred to specialists within library departments or to each and every librarian in the form of basic computer competencies, and wonder if this 
trend will be the one to significantly alter the systems librarian role. We also can look to technological trends such as the growth in new architecture designs for integrated library systems, database construction, and office applications, and ponder the effect of these innovations on this role. Have we yet seen the full effect of the consortial agreements being made to purchase access to or share electronic information? Will national and international standards mature to the point of seamless internetworking and sharing of data? Will some of these trends significantly alter the role of the systems librarian and move us into a new stage?

Will we know before, or even when, this new stage is here, or will we only recognize it in retrospect and have to adjust our role to fit it? We have seen how the changes to the role of systems librarian in the networked stage have resulted in certain trends in the academic library. We will need to monitor these trends in the coming years and analyze if they are appropriate reactions to fundamental changes in technology, such as the introduction of internetworking. In the period following Martin's 1988 article pointing out the lack of research into the role of the systems librarian, there has been a slow increase in the number of articles, surveys, and books published that study the role and the technological and managerial challenges of the systems librarian in the modern library. The lack of research in previous stages left us with little information to guide us as we reacted to technological changes during the current stage. This burgeoning interest in the role of the systems librarian will help us to monitor the changes that occur, ask why they are occurring, and dynamically change our roles and organizations so that we can continue to offer new, more useful information services to our patrons in the most efficient and effective way.

\section{Notes}

1. Susan K. Martin, "The Role of the Systems Librarian," Journal of Library Administration 9, no. 4 (1988): 57.

2. Barbara G. Leonard, "The Role of the Systems Librarian/Administrator: A Preliminary Report," Library Administration \& Management 7, no. 2 (spring 1993): 113-16; Karen A. Hatcher, "The Role of the Systems Librarian/Administrator: A Report of the Survey," Library Administration \& Management 9, no. 2 (spring 1995): 106-9.

3. Scott P. Muir, Library Systems Office Organization, SPEC Kit \#211 (Washington, D.C.: ARL Office of Management Studies, 1995).

4. Graeme A. Muirhead, "The Role of the Systems Librarian in Libraries in the United Kingdom," Journal of Librarianship and Information Science 25, no. 3 (Sept. 1993): 123-35.

5. Muir, Library Systems Office Organization.

6. Susan B. Epstein, "Administrators of Automated Systems: A Survey," Library Journal 116, no. 11 (June 1991): 56; Leonard, "The Role of the Systems Librarian/Administrator," 115.

7. There were scattered cases of automation in libraries beginning as early as 1936. For more in-depth coverage of the history of library automation, see The Encyclopedia of Library and Information Science (New York: Marcel Dekker 1975), 338-445; and Charles R. Hildreth, Library Automation in North America (New York: Saur, 1987).

8. The Encyclopedia of Library and Information Science, 339-42.

9. It is interesting to note that in 1975 The Encyclopedia of Library and Information Science states that "the vast majority of existing systems" fall into these categories: acquisitions, cataloging, serials, and circulation (p. 343). Hildreth, in Library Automation in North America, tells us that in 1980, the phrase "online public access catalog" was not a familiar one "in the common parlance of library networkers" (p. 5).

10. Hildreth, Library Automation in North America, 17.

11. Eleanor Montague, "Automation and the Library Administrator," Journal of Library Automation 11, no. 4 (Dec. 1978): 315.

12. Tom Mendina, "The Role of the Library Project Manager in Implementing an Automated Circulation-Online Catalog System," Journal of Library Administration 4, no. 3 (fall 1983): 36-37; 
William Atkins, "Selecting a Project Manager," Systems Management 31, no. 10 (Oct. 1980): 34-35.

13. Mendina, "The Role of the Library Project Manager," 37.

14. Hildreth, Library Automation in North America, 9-10.

15. Hatcher, "The Role of the Systems Librarian/Administrator," 107.

16. R. Bruce Miller, Systems Office Organization, SPEC Kit \#128 (Washington, D.C.: ARL Office of Management Studies, 1986).

17. For an overview of internetworking protocols, see, for example, Gilbert Held, Internetworking LANs and WANs: Concepts, Techniques, and Methods (New York: John Wiley, 1993).

18. Clifford A. Lynch, "Evolution in Action: The Demise of the Integrated Library System and the Rise of Networked Information Resources," in Computers in Libraries '91: Proceedings of the 6th Annual Computers in Libraries Conference, ed. Nancy M. Nelson (Westport, Conn.: Meckler, 1991), $106-7$.

19. Muir, Library Systems Office Organization.

20. Muirhead, "The Role of the Systems Librarian in Libraries in the United Kingdom," 129.

21. Hatcher, "The Role of the Systems Librarian/Administrator," 107.

22. Tim Lynch, "The Many Roles of an Information Technology Section," Library Hi Tech 12, no. 3 (1994): 42.

23. Muir, Library Systems Office Organization.

24. Leonard, "The Role of the Systems Librarian/Administrator," 116.

25. Ibid., 115.

26. Muirhead, "The Role of the Systems Librarian in Libraries in the United Kingdom," 133.

27. Yuan Zhou, "Analysis of Trends in Demand for Computer-Related Skills for Academic Librarians from 1974 to 1994," College E Research Libraries 57, no. 3 (May 1996): 261.

28. Muir, Library Systems Office Organization.

29. Muirhead, "The Role of the Systems Librarian in Libraries in the United Kingdom," 133.

30. Felix T. Chu, "Evaluating the Skills of the Systems Librarian," Journal of Library Administration 12, no. 1 (1990): 101.

31. Muirhead, "The Role of the Systems Librarian in Libraries in the United Kingdom," 134.

32. Epstein, "Administrators of Automated Systems," 57.

33. Muir, Library Systems Office Organization.

34. Muirhead, "The Role of the Systems Librarian in Libraries in the United Kingdom," 130.

35. Ibid.

36. David J. Ernst, Richard N. Katz, and John R. Sack, Organizational and Technological Strategies for Higher Education in the Information Age, CAUSE Professional Paper Series 13 (Boulder, Colo.: CAUSE, 1994). 